Please do not remove this page

RMIT

UNIVERSITY

\title{
Market orientation and marketing in nonprofit organizations. Indications for fundraising from Victoria
}

Brady, Erica; Brace-Govan, J; Brennan, Linda-Marie; Conduit, J

https://researchrepository.rmit.edu.au/esploro/outputs/9921858208901341/filesAndLinks?institution=61RMIT_INST\&index=null

Brady, E., Brace-Govan, J., Brennan, L.-M., \& Conduit, J. (2010). Market orientation and marketing in nonprofit organizations. Indications for fundraising from Victoria. International Journal of Nonprofit and Voluntary Sector Marketing, 16, 84-98. https://doi.org/10.1002/nvsm.403

Document Version: Submitted Version

Published Version: https://doi.org/10.1002/nvsm.403

Repository homepage: https://researchrepository.rmit.edu.au

(c) 2010 John Wiley \& Sons, Ltd

Downloaded On 2023/04/26 19:11:28 +1000

Please do not remove this page 


\title{
Market Orientation and Marketing in Nonprofit Organizations.
}

\author{
Indications for Fundraising from Victoria
}

\section{THIS IS THE PRE-PEER REVIEWED VERSION OF THE FOLLOWING ARTICLE:}

Brace-Govan, J., Brady, E., Brennan, L., \& Conduit, J. (2011). Market Orientation and marketing in nonprofit organisations - Indications for fundraising from Victoria International Journal of Nonprofit and Voluntary Sector Marketing, Vol. 16 No. 1, pp. 84-98.

WHICH HAS BEEN PUBLISHED IN FINAL FORM AT.

HTTP://ONLINELIBRARY.WILEY.COM/DOI/10.1002/NVSM.403/ABSTRACT 


\begin{abstract}
The effectiveness of a market orientation has been established in other parts of the world. Using a modified replication study of 401 nonprofit organizations from Victoria, this research took some initial steps to assess fundraising and marketing activities. Studies in Australia have usually focused on only one part of the Third Sector. This study takes a different view and uses a criteria sampling method to survey all eleven sections named by the Australian Bureau of Statistics. The self-reported data of fundraising activities showed that there were several choices available to all nonprofit organizations that can lead to an improvement in organizational performance. Results suggest that should nonprofit organizations have knowledge generating systems that evaluate their performance this will improve outcomes for them. Even though organizational size is strongly linked to fundraising performance, there are key drivers that can aid even small organizations in their efforts.
\end{abstract}

Keywords: Market orientation, fundraising, organizational performance 


\section{INTRODUCTION}

There is a growing body of literature that asserts the importance of marketing and marketing activities for nonprofit organizations (White and Simas, 2008), nevertheless there is a need for information that describes the third sector in terms of marketing activities. Market orientation has been extensively researched in the commercial sector and, although organizational commitment is still under scrutiny, it has generally been found to be of value to organizational performance overall (Sivaramakrishnan et al., 2008). However, the crucial underpinning assumptions of profit motivation and thus the fundamental value of marketing to the organization do not necessarily hold for the third sector (White and Simas, 2008). The relevance of the concept market orientation to the nonprofit sector has been challenged and a societal orientation suggested (Sargeant et al., 2002). Others have found market orientation to be wanting and subsequently extended the model for arts organizations (Gainer and Padanyi 2005). Indeed, most information about market orientation in the nonprofit environment focuses on single sectors (Caruana et al., 1998a, 1998b; Ewing and Caruana, 2000; Harrison and Shaw, 2004; White and Simas 2008). An aim of this paper is to map the current state of marketing orientation and its link to performance across a broad range of nonprofit organizations in the Australian third sector.

A consideration of marketing orientation in this region further develops work on single sectors (Ewing and Caruana, 2000; Harrison and Shaw, 2004; Zhou, Chao and Huang 2009) and is warranted given the expansion of the sector since the 1980s (Dolnicar and Lazarevski 2009, 281). In comparison to the UK and the USA, Australia has a smaller population, although like these two countries the median age is rising (Dolnicar and Lazarevski 2009, 279) thus increasing the pressure on some sections of the nonprofit industry. In the UK the nonprofit system is centralized through the Charitable Commission which has the effect of improving the equity of distribution of government funding (Dolnicar and Lazaevski 2009, 280). At 700,000 organisations (Philanthropy Australia, 2010), Australia has fewer nonprofits than both the UK and the USA, but in terms of its contribution to employment is of a similar size to both these countries (National Roundtable of Nonprofit Organizations, 2007). Regulation is through three layers of government (local, state and federal), and "deductible gift" status is determined through the Australian Tax Office (National Roundtable of Nonprofit Organizations, 2007). The Australian Bureau of Statistics provided a definition of nonprofit institutions (ABS 2009) to 
facilitate joining the international research project managed by the Center for Civil Society Studies at Johns Hopkins University. In 2006, 34\% of Australians volunteered and nonprofit organizations contributed $4.1 \%$ to the Australian economy (ABS 2009).

\section{THE MARKETING CONCEPT IN THE NONPROFIT SECTOR}

Although marketing is widely perceived to be essential to organizations that have to attract revenue from external sources, the applicability of marketing in nonprofit settings has been debated (Padanyi 2008) and some suggest research here remains limited (Gonzalez et al., 2002). Marketing can be seen as a philosophy, a process, a culture, a set of tools or a management process (Sargeant 2005). The erroneous and somewhat limited view of marketing as public relations or, advertising and selling (Balabanis et al., 1997) leads some nonprofits to hold quite negative attitudes towards marketing and continues today (Dolnicar and Lazarevski 2009). Some researchers argue that many nonprofits struggle with some of the key business concepts (Sargeant et al., 2002). Adaptations are suggested to tackle some of the differences around, either the characteristics of the organizational mission (Sargeant et al., 2002), or the influence of sector specific factors (Gainer and Padanyi 2005), or the characteristics of the staff (Sui and Wilson 1998). Other important differences between nonprofits and the commercial sector regularly repeated by leading researchers are: nonprofits have multiple constituencies; nonfinancial objectives and; a focus on service (Andreasen and Kotler 2008). Nonprofits also need to be responsive to non-market pressures, such as government policy (Sargeant 2005). Although commercial organizations must also respond to policy, nonprofit organizations often deliver services on behalf of governments, particularly in the health and community sectors. Nonprofits are often open to intense public scrutiny and are usually accountable to more than one stakeholder group (Andreasen and Kotler 2008). This is often further compounded by the role that nonprofits take in social marketing and advocacy whereby they engage in encouraging changes in behavior and the consideration of different value positions.

Notwithstanding these tensions, which have been debated in the literature for several years (Padanyi 2008), recent work from the UK has established that most of the large nonprofit organizations are more corporatized and make extensive use of the marketing concept in their 
activities (Seymour et al., 2006). Bennett (1998a) identified a link between market orientation and the fundraising performance of small and medium sized nonprofits in the UK. Other research has also demonstrated a link between organizational performance and market orientation (Kirca et al., 2005; Rodriguez et al., 2004) and found that market orientation was especially successful in service orientation and nonprofit organizations. However, although the effectiveness of a market orientation has been asserted in the nonprofit sector, work has focused on the UK (Balabanis et al., 1997; Bennett 1998a, 1998b; Sargeant et al, 2002), Spain (Gonzalez et al., 2002; Vazquez et al., 2002) and the US (Kara et al., 2004; 2005) there is quite limited information regarding Australian nonprofits. Australian studies tended to focus on single sectors such as education (Caruana et al., 1998a, 1998b; Ewing and Caruana, 2000;) or libraries (Harrison and Shaw, 2004). There was a need to gather a broader picture of the nonprofits in Australia, to describe the extent of marketing within Australian nonprofit sector, and whether or not market orientation extended beyond larger nonprofits.

In addition, the plethora of models and ideas existing in the various domains presents a dilemma for researchers and practitioners in the field. Adopting a marketing orientation could be a highrisk strategy for a nonprofit. As a consequence there is a need for greater certainty with regard to the link between performance and orientation. Such certainty can only be gained if sufficient data is gathered that replicates the outcomes under a variety of conditions (cf. Easley Madden and Dunn 2000). There are several replication studies in marketing orientation in the commercial sector but, it would appear that there are very few in the nonprofit sector. However, it would be useful to do this through the replication of another similar study in order that an implied comparison can be made. A study by Bennett (1998b) was used because the Australian third sector has, in the past, drawn from the UK for some of its legal definitions (Sargeant 2005).

\section{MARKET ORIENTATION FOR THE THIRD SECTOR}

Over the last three decades the nonprofit, or third sector, has undergone significant changes and nonprofit organizations face increasing pressures from the external environment. This includes government, international and domestic influences; changes in lifestyle affecting the availability of volunteers, and the consideration of competition (Bennett and Sargeant, 2005; Lyons 2001). 
While many nonprofits have adopted marketing to survive these changes, there is less evidence to suggest that they have done so willingly (Bennett and Savani 2004; McDonald 2007).

The expectation of marketing in nonprofit organizations has been to raise awareness, or to improve fundraising performance (Arbuthnot and Horne 1997). Many have noted a restricted application of marketing in comparison to commercial, or for profit marketing and noted a lack of attention to marketing as a guiding philosophy, or as a strategic or planning tool (Balabanis et al., 1997; Bennett 1998a; Buchanan et al., 1987; Smith and Santandreu R 1997; Wrenn et al., 1994). More recently however, terms such as 'market(ing) orientation', 'customer focus' and 'marketing concept' characterise the philosophy that a nonprofit organization is exhorted to have, or direct the activities they should undertake. Several studies have evaluated the presence and impact of this more strategic approach to marketing (Balabanis et al., 1997; Bennett 1998a; Chan and Chau 1998; Sargeant et al., 2002; Wood and Bhuian 1993; Wrenn 1996).

Briefly, there are two schools of thought regarding market orientation (Padanyi 2008). One school suggests that market orientation is behavioral, that is organizations, do certain marketing activities (Jaworski and Kohli, 1993). The other school argues that market orientation is a culture that the organization has that predisposes it to behave in a certain way (Narver and Slater 1990). The key component of both schools is that the organizations have an orientation, or focus, toward the customer (and competitors) and use the knowledge they gather about the needs and wants of the customer in their decision making. The underlying premise is that a market orientation leads to improved performance. The advantage of utilizing the behavioral approach of Kohli et al (1993) is that should an organization implement market orientation as a business strategy, no specific alterations to organizational culture are necessarily required (Padanyi 2008). This is important because recent research has identified a lack of marketing knowledge in nonprofit organizations across the USA, UK and Australia (Dolnicar and Lazarevski 2009; Zhou et al., 2009) and Bennett (1998b) suggested that some third sector organizations had an antimarketing bias. Therefore being able to identify appropriate processes would be useful. Business strategies are becoming more widespread in the third sector (Dolnicar et al., 2008; Goerke 2003) and a comparative advantage is available to nonprofit organizations that adopt a more customer orientated stance (Rodriguez et al., 2004, p. 191). Indeed a focus on the 
customer in order to bring about the behavioral change required by social marketing, often the domain of nonprofit organizations, is strongly reinforced by the UK health initiative the National Social Marketing Centre (2010). Thus, in spite of the unique characteristics of nonprofit organizations (Dolnicar and Lazarevski 2009), a valuable response from nonprofit organizations to the increasing competition for scarce resources would be to engage in activities that allow a better understanding of customers, competitors and to ensure that this information is quickly disseminated through the organization.

Following Bennett (1998b), and others (Caruana et al., 1998a, 1998b; Evans et al., 1996; Zhou et $a l ., 2009$ ) this study adopted Kohli and Jaworski's measure of market orientation - MARKOR, with some minor modifications in language appropriate to the Australian nonprofit sector. To date the results of these studies suggest that there is a relationship between market orientation and performance in the nonprofit context. However, as mentioned previously, these studies have been conducted within a single organizational context or have focused on certain sectors of the nonprofit context. Although the implicit assumption that market orientation is equally applicable to all nonprofits irrespective of their raison d'etre has been challenged (Bennett 2005; Gainer and Padanyi 2005; Kara et al., 2004), no work has been found that compares the presence of, or impact on performance of, market orientation across different types of nonprofits. Additionally given the increasing pressures faced by nonprofit organizations it is argued that the level of market orientation exhibited is important to record.

\section{METHOD}

With such limited foundation work, it would be useful to have a benchmark of Australian data that may be compared with other countries where such data is available and into the future. However, it would be useful to do this through the replication of another similar study in order that an implied comparison can be made. A study by Bennett (1998b) was used because the Australian third sector has, in the past, drawn from the UK for some of its legal definitions (Sargeant 2005). Also a recent study by Dolnicar and Lazarevski (2009) showed that, despite regulatory, demographic and size of sector variations, there were surprisingly few differences across the USA, UK and Australian nonprofits, making this survey instrument applicable. Replication studies are useful to social science because they are a necessary ingredient for knowledge advancement (Easley et al, 
2000). There are four types of replication study that range from precise duplication, which is not possible in social science (Easley et al., 2000, p85), through to a modified replication where there is "deliberate modification of a prior study" (Easley et al., 2000, p85). A modified replication is especially useful once a theory has been tested to offer a further contribution to understanding phenomena (Easley et al., 2000, 88), as is the case here.

This research explored market orientation in a comprehensive range of nonprofit sectors in Victoria, Australia. Victoria is neither one of the largest nor one of the smallest states in terms of geographic area, nor is it one of the fastest or slowest growing states with regard to population. With a population of around 5 million, Victoria is a reasonably densely populated state, with a substantial capital city, Melbourne, and a rural area that does not qualify as remote. As such Victoria is a better comparator to the UK than for example Western Australia where remoteness and low density of population plays a significant role (ABS 2009).

The MARKOR scale was incorporated into a survey instrument following Bennett's (1998b, p37) survey. The purpose was to examine the broader nonprofit sector in Victoria, Australia therefore the wording 'charity' was changed for 'nonprofit'. Charity was unnecessarily limiting and is not the usual expression in Australia. A modification for this study was the inclusion of a broader range of organizations. Although Bennett limited his study to exclude the largest charities, this study used quota sampling to upweight the smaller organizations and ensure that their presence in the sample. The quota sampling process also ensured that all named categories of nonprofit were surveyed but that the more substantial sectors did not dominate. For example the health and social services are sectors with a high number of organizations and also a high number of large organizations. In contrast the culture and recreation sector organizations are quite numerous but are often smaller. The sample was larger than Bennett's to accommodate these modifications. In order to be able to sort for organizational size the survey included questions about organizational size, and was restricted to organizations with more than five staff. Size was established by asking about the numbers of employees, both volunteer and paid; and the annual turnover of the organization. A second modification that extended the survey was to inquire about the extent of support for the marketing function. For this the survey asked how many marketing staff there were; the allocated marketing budget; and the main sources of revenue for 
the organization. Donor orientation and fundraising were the focus of the survey questions.

The survey was conducted by telephone (Computer Aided Telephone Interviewing, CATI) with all sectors of the third sector represented. A quota sampling method was used to ensure that a cross section of all named sectors in Victoria was achieved (Bordens and Abbott 2005) and at least 30 responses per sector were attained; resulting in a total of 401 participants. The CATI enabled the data to be collected from a variety of different organizations in a relatively short space of time (over two weeks). It also enabled the interviewer the opportunity to find the right person within the organization regardless of the nominal title, as many 'marketing' activities are not carried out by 'marketers' (Seymour et al., 2006). The 11 sectors as defined by the International Classification of Non-Profit Organizations (ICNPO) are replicated in the Australian and New Zealand Standardized Industrial Classification (ANZSIC) (ABS 2002) and all these were successfully surveyed. The $12^{\text {th }}$ category was omitted because "miscellaneous" is a nomenclature applied by the ABS data gathering process and organizations rarely label themselves as such. Organizations allocated to miscellaneous are not that numerous to be a limitation. Organizational contact details were ascertained via telephone books and industry lists. Using these criteria, it was anticipated that no sector would dominate the responses and a range of organizational sizes would be represented. The profile of respondents is contained in Table One.

\section{INSERT TABLE ONE ABOUT HERE}

\section{RESULTS}

The results of the replication of Bennett's (1998b) survey are presented in Table Two. As can be seen, the mean values presented in Table Two suggest that the nonprofit organizations sampled in this research are strongest at generating information on their donors and maintaining an understanding of competitor activities and acting on this information. Overall they are weakest on aspects such as understanding their donor base and evaluating the effectiveness of their overall programs.

\section{INSERT TABLE TWO ABOUT HERE}


In comparison to the research undertaken by Bennett the current data has lower levels of reliability as assessed by Cronbach's alpha (1951) and shown in Table Three. This could suggest that the structure of the market orientation model in this context could be re-examined so that scale items could be adapted to better reflect the Australian context. Alternatively, as recent literature has suggested (Coltman et al 2008) it may be more appropriate to consider market orientation as formative model. However this study, remaining consistent with Bennett (1998b) and the majority of work in the area continues to treat the construct reflectively.

\section{INSERT TABLE THREE ABOUT HERE}

To further examine the differences identified, a factor analysis using principal components, varimax rotation was undertaken. This process mirrors that used by Bennett and others in examining the dimensions of the MARKOR scale. While this produces very similar dimensions of market orientation to that of Bennett, the underlying items within each dimension are quite different. Table Four illustrates the factor and item loadings.

\section{INSERT TABLE FOUR ABOUT HERE}

These results suggest that the behaviors which constitute donor orientation, competitor orientation, and marketing integration are different in the Australian context. In addition, there are a number of cross product loadings which would indicate that the dimensions are not as clear cut as they ought to be in such an evolved theoretical concept. As a consequence, further research might be in order to more clearly articulate the concepts as applied to the nonprofit context.

The revised model shown in Table Four differs in a number of ways to the dimensions in Bennett's work. Based on our research three additional items can be considered to be part of donor orientation:

(1) quickly detect changes in patterns of donations,

(2) have systems to determine the value and frequency of donations and 
(3) set precise targets for fund raising programs.

Additionally, Bennett included items reflecting fund raising performance as part of a donor orientation. This model found that the items related to fund raising performance loaded separately to these "activity based" items and possibly represent a performance outcome of being market oriented (not shown above). To be competitor oriented, organizations in the current research also regularly compare their fund raising performance against others. Factors that were present in the Bennett model that loaded independently in this research reflected the competitive intensity of the industry (which could drive market orientation) rather than a market orientation itself.

The Marketing Integration dimension also included two new items in addition to the three in Bennett's original study. These items are:

(1) people and departments getting together to plan responses and experimenting and

(2) experimenting and innovating with promotional matter.

Our model (3 dimensions) explains $36 \%$ of the variance in the data. It is worth noting that one of Bennett's original items "survey a sample of donors at least once a year" loaded equally on a donor orientation and a competitor orientation and was therefore not included in either dimension.

\section{Market orientation and fundraising performance}

In the current research the indicator of interest is fundraising performance. The drivers of fundraising performance are shown in Table Five.

\section{INSERT TABLE FIVE ABOUT HERE}

Bi-variate correlation analysis was conducted and Table Five shows the Pearson Correlation coefficient of each of the items and the factors on which they loaded. Although the correlation figures are low suggesting that these items of market orientation are only a small part of what drives people's perception of their fund raising performance, there is a key theme. The drivers of performance are not uniform across the dimensions of market orientation, nor are they explained by one of the factors in particular. What the data does indicate is that the activities more strongly related to fundraising performance are related to processes and procedures that create knowledge 
about donors rather than the knowledge about donors per se. That is, a nonprofit which surveys their donors, sets targets, has knowledge generating systems and evaluates their performance will have more fundraising performance success. Interestingly, there is a negative relationship between competitive intensity and fund raising performance, suggesting it is easier to generate funds in a less competitive environment. Where there are many fundraisers in the field, attempting to gather a larger 'share of wallet' is more difficult for an individual organization.

This rationale underpins the experience of fundraising after the Victorian Bushfires of 2009 where the nonprofit organizations combined to allow a single organization to manage the collection of funds rather than competing with each other for smaller shares. In this way the media attention and fundraising efforts could be efficiently channeled. This collaboration resulted in a much greater donation amount overall than was predicted had all the relevant charities been independently fundraising at the same time. In this way co-opetition rather than competition resulted in more money being donated overall. People were not being asked to choose a charity. They were being asked to donate to an immediate and terrible emergency.

\section{Key differences across sectors}

Given the nature of market orientation and the broad scope of the nonprofit sector it is reasonable to expect that there may be differences in the responses from the different sectors. However, the results of a one-way ANOVA do not support this proposition. The means of scores across the various segments are not significantly different on the market orientation scale with two exceptions. The two items that exhibited differences were "survey a sample of donors at least once a year" and "information gathered by marketing people is shared with others". As can be seen in Table Six religious organizations had significantly lower means on the item "survey a sample of donors" than the other categories, in particular business and professional associations and philanthropic intermediaries. Further, philanthropic organizations would appear to have less sharing of marketing information than the other types of organization. One reason for this is that philanthropic organizations would have less need to share information of this type. A philanthropic organization is mostly likely to be dealing with organizations seeking donations rather than individuals as donors or clients. In marketing terms, this would be considered as a business-to-business rather than a business-to-consumer context, with commensurate changes in 
strategy required.

\section{INSERT TABLE SIX ABOUT HERE}

Whilst there is little difference between the groups based on the nature of the organization there are differences based on the turnover of the organization. Using turnover as an indicator of size, this finding is consistent with the suggestion that many of the differences in firms (including marketing activities) is a function of size rather than the nature of the organization (cf Seymour et al., 2006). That is, large organizations, irrespective of their nature or sector, behave like large organizations and small organizations exhibit similar characteristics (Coviello et al., 2000). As can been seen in Table Seven those organizations with a turnover of greater than AUD\$1 million $(\mathrm{n}=117)$ exhibited higher levels of many of the indicators of market orientation than those organizations with a lower turnover. Three of the items which had significant differences relate to the donor orientation construct. In particular these items focus on systems or policies that the organizations have. Further research could establish whether this difference is due to more sophisticated business practices or, requirements for greater accountability by funding bodies and government or alternatively if the issue is simply one of organizational size. In which case, the concept of critical mass becomes important in designing nonprofit organizations.

\section{INSERT TABLE SEVEN ABOUT HERE}

Two items (indicated by $* *$ in table) which had significantly different means between high and low turnover organizations did not load on the market orientation scale. This may suggest that organizations with greater resources are able to move "beyond the basics" of fundraising and consider marketing from a more holistic perspective. The mean of responses to the item "survey a sample of donors at least once a year" (indicated by \#\# in table) was also significantly higher in higher turnover organizations. As noted earlier this item cannot be classified as belonging to either a competitor or donor orientation but seems to consistently be an indicator of differences between organizations. It could be argued that higher turnover organizations have the resources to conduct surveys, or they have a larger donor base that requires sampling. This may be in comparison to smaller organizations that could be closer to their donor base. A close knit donor 
relationship might not need to use formal methods of research to understand.

\section{DISCUSSION}

This research utilized Bennett's (1998b) development of the marketing orientation MARKOR survey to gain a better description of the marketing function in nonprofit organizations in Australia. It is evident that larger organizations appear to be more effective performers. However, the research identified that smaller aspirational nonprofit organizations could readily implement a (very) few activities to ensure that their own performance is improved. A key driver in this instance was the annual survey of donors which clearly made a difference to performance and is therefore worth considering in developing new models of operation. It must be noted that the term 'survey' in the small nonprofit context might be a relatively simple affair and may not require any formal process. In addition, to an annual survey, monitoring the market for competitor activities and benchmarking performance against other organizations was also important. These elements suggest that being sufficiently externally focused through benchmarking and surveying opens up possibilities for organizations and increases the likelihood of innovation and change. This might enable an organization to see and take advantage of opportunities to serve their markets more readily than more internally focused organizations.

The use and application of information was also an important driver of performance. It was clear that the processes by which an organization collected and used information were what provided the support for fundraising performance. Significantly, it may not be what information is collected; merely that it is collected, disseminated and applied. This suggests that the process may be more important than the outcome and further research around this would be useful. As has been noted in the past, one of the difficulties of marketing in nonprofit organizations was the lack of marketing knowledge held by managers and administrators (Wrenn et al., 1994). Potentially larger organizations have processes which enable or demand wider dissemination. In addition, the effect of size of organization goes some way to explain the variations between Bennett's study and the one reported here. The focus on diversity of organizations and gathering information across the whole sector was a key a difference to the Bennett study, where only small and medium sized organizations were included. 
This study has illustrated that the quest for applying commercial (marketing) concepts to the nonprofit sector is not completed. Much is still unanswered with regard to market orientation and organizational performance. For example, the existence of processes that facilitate market orientation without the apparent need to adopt a specific marketing culture deserves further examination. This result begs the question of whether or not a philosophy needs to be disseminated throughout the organization or whether ensuring processes exist makes certain that market oriented activities take place. The conflict between marketing and other functions in the nonprofit sector has been reported for the UK (Bennett and Savani 2004) so the need to find other rationales could be anticipated. Research that uncovered the depth and presence of marketing in nonprofit organizations would be valuable. In their international comparison, Dolnicar and Lazarevski (2009) found only a minor role for market research and a lack of staff trained in marketing impeded the adoption of a market orientation across nonprofit organizations. Zhou, Chao and Huang (2009) examined market orientation in a state owned enterprise that engaged with social marketing and they too noted a need for improved market research, as well as the critical role of professional development for managers to "enhance the adoption and implementation of market orientation" $(2009,268)$.

In addition, it is worthwhile considering whether each of the 11 sectors has specific intervening conditions that could be accounted for and incorporated into nonprofit business strategy (cf Gainer and Padanyi 2005). Another fruitful avenue would be to investigate specific approaches such as relationship marketing, particularly when a sector's funding is derived primarily from grants as opposed to soliciting donations (cf Bennett 2005). Recalling the close links between nonprofit organizations and government noted earlier, establishing connections to the public service could be especially pertinent to nonprofit sectors. Another significant facet is the pursuit of social marketing strategies in order to communicate behavioral and societal change to the general public that are widely utilized by nonprofit organizations. The key drivers identified with this research could be examined in further depth including comparisons across sectors to highlight any significant variations and, specific nonprofit situations could be investigated to better understand the cultural role of the annual survey in enhancing performance. Finally, given the reliance of market orientation on the concept on competition and the machinations of the competitive marketplace, further consideration needs to be given to pursuing societal marketing 
as an appropriate rationale for nonprofit organizations. The argument presented by Sargeant, Foreman and Liao (2002) notes the broader social imperatives that underpin most nonprofit missions and their potential lack of congruence with rational economic exchange.

\section{CONCLUSION}

Market orientation continues to be of interest to scholars. When market orientation is expressed as a focus on fundraising there is a clear link to organizational performance. Further, there are key activities which lead to improved organizational performance. Although the size of the organization influences success, the results from this study demonstrate that there are very specific activities which can lead to better outcomes for organizations of all sizes. Consequently, smaller and medium nonprofits can hope for success regardless of their resource constraints. Finally there continues to be a need for more research, for example around the effect of processes regardless of culture and in comparison across different types of nonprofit organizations. 


\section{REFERENCES}

Andreasen A. Kotler P. 2008. Strategic Marketing for Nonprofit Organizations, $7^{\text {th }}$ ed. Prentice Hall: Upper Saddle River NJ.

Arbuthnot S, Horne S. 1997. The marketing activities of UK charities. Journal of Nonprofit and Public Sector Marketing 5 (1): 63-79.

Australian Bureau of Statistics. 2002. 5256.0 - Australian National Accounts: Non-Profit Institutions Satellite Account, 1999-2000 Canberra, Australia: Australian Bureau of Statistics.

Australian Bureau of Statistics. 2009. 5256.0 - Australian National Accounts: Non-Profit Institutions Satellite Account, 2006-2007, Media Release Canberra, Australia: Australian Bureau of Statistics.

Australian Government, Australian Taxation Office. 2007. Non-profit organizations, available at: www.ato.gov.au/non-profit/ (accessed June 2010).

Balabanis G, Stables RE, Phillips HC. 1997. Market orientation in the top 200 British charity organizations and its impact on their performance. European Journal of Marketing 31 (8): 583603.

Bennett R. 1998a. Charities, organizational learning and market orientation: A suggested measure of the propensity to behave as a learning organization. Journal of Marketing Practice: Applied Marketing Science 4 (1): 5-25.

Bennett R. 1998b. Market orientation among small to medium sized UK charitable organisations: Implications for Fund-Raising Performance. Journal of Nonprofit \& Public Sector Marketing 6 (1_3): 31-45. 
Bennett R. 2003. Competitor analysis practices of British charities. Marketing Intelligence \& Planning 21 (6): 335-345

Bennett R. 2005. Competitive environment, market orientation, and the use of relational approaches to the marketing of charity beneficiary services. The Journal of Services Marketing 19 (7): 453-469.

Bennett R, Gabriel H. 1998. Direct marketing managers in UK charitable organisations. Journal of Nonprofit and Voluntary Sector Marketing 3 (2):160-172.

Bennett R, Sargeant A. 2005. The nonprofit marketing landscape: guest editors' introduction to a special section. Journal of Business Research 58 (6): 797-805.

Bennett R, Savani S. 2004. Managing conflict between marketing and other functions within charitable organisations. Leadership \& Organization Development Journal 25 (2): 180-200.

Bordens KS, Abbott BB. 2005. Research design and methods: A process approach. 6th ed. McGraw Hill: New York.

Buchanan WW, Self D, Ringram JJ. 1987. Non-profit services: adoption or adaption of marketing. Journal of Professional Services Marketing 2 (4):83-93.

Caruana A, Ramaseshan B, Ewing MT. 1998a. Do universities that are more market orientated perform better? The International Journal of Public Sector Management 11 (1): 55-70.

Caruana A, Ramaseshan B, Ewing MT. 1998b. The market orientation - performance link: Some evidence from the public sector and universities. Journal of Nonprofit \& Public Sector Marketing 6 (1): 63-82.

Chan R, Chau A. 1998. Do marketing - oriented children and youth centres (CYCs) perform 
better: An exploratory study in Hong Kong. Journal of Professional Services Marketing 16 (1): $15-28$.

Coltman, T., Devinney, T. M., Midgley, D. F., Venaik, S. 2008. Formative versus reflective measurement models: Two applications of formative measurement. Journal of Business Research, 61(12): 1250-1262.

Coviello NE, Brodie RJ, Munro HJ. 2000. An investigation of marketing practice by firm size. Journal of Business Venturing 15:523-545.

Cronbach, LJ. 1951. Coefficient Alpha and the internal structure of tests. Psychometrika 16 (3): 297-333.

Dolnicar, S. Lazarevski, K. 2009. Marketing in non-profit organizations: An international perspective, International Marketing Review, 26 (3): 275-291.

Dolnicar, S. Irvine, H. Lazarevski, K. 2008. Mission or money? Competitive challenges facing public sector nonprofit organizations in an institutionalized environment, International Journal Nonprofit Voluntary Sector Marketing, 13: 107-117.

Evans A, James T, Tomes A. 1996. Marketing in UK sport associations. Service Industries Journal 16 (2): 207-222.

Ewing MT. Caruana A. 2000. Marketing within the public sector. Journal of Nonprofit \& Public Sector Marketing 8 (1): 3-15.

Gainer B, Padanyi P. 2005. The relationship between market-oriented activities and marketoriented culture: implications for the development of market orientation in nonprofit service organizations. Journal of Business Research 58 (6): 854-862. 
Gonzalez L, Vijande M. Casielles R. (2002) The Market Orientation concept in the private nonprofit organization domain, Int. Journal of Nonprofit and Voluntary Sector Marketing, 7, (1) 55-67.

Harrison PJ, Shaw RN. 2004. Intra-organisational marketing culture and market orientation: a case study of the implementation of the marketing concept in a public library Library Management 25 (8/9): 391-398.

Hayden V. 1992. How market-oriented is your service? Journal of Management in Medicine 6 (1):5-9.

Jaworski BJ, Kohli AJ. 1993. Market Orientation: Antecedents and consequences. Journal of Marketing 57 (July): 53-70.

Kara A, Spillan JE, DeShields OW. 2004 An empirical investigation of the link between market orientation and business performance in non-profit service providers. Journal of Marketing Theory and Practice12 (2): 59 - 72

Kara A, Spillan JE, DeShields OW. 2005. The effect of a market orientation on business performance: a study of small-sized service retailers using MARKOR scale. Journal of Small Business Management 43 (2): 105-118.

Kirca AH, Jayachandran S, Bearden W. 2005. Market orientation: a meta-analytic review and assessment of its antecedents and impact on performance. Journal of Marketing; 69 (2):24-.

Kohli AK, Jaworski BJ, Kumar A. 1993. MARKOR: A measure of market orientation. Journal of Marketing Research XXX (3): 467-77.

Kohli AK, Jaworski BJ. 1990. Market Orientation: The construct, research propositions, and managerial implications. Journal of Marketing 54 (April): 1-13. 
Lamb CW, Crompton JL. 1986. Contrasting marketing and selling orientations in government organisations. Journal of Professional Services Marketing 1 (1): 157-67.

Lyons M. 2001. Third Sector: the contribution of nonprofit and cooperative enterprises in Australia. Allen \& Unwin: Crows Nest, NSW.

McDonald RE. 2007. An investigation of innovation in nonprofit organizations: The role of organizational mission. Nonprofit and Voluntary Sector Quarterly 36 (2): 256-281.

Narver JC, Slater SF. 1990. The effect of a market orientation on business profitability. Journal of Marketing 54 (October): 20-35.

National Social Marketing Centre. 2010. Available at: www.nsmc.org.uk (accessed June 2010).

National Roundtable of Nonprofit Organizations. 2007. The nonprofit sector in Australia, "About the NFP Sector", available at: www.nonprofitroundtable.org.au/ (accessed June 2010).

Padanyi P. 2008 Operationalizing the marketing concept: Achieving Market Orientation in the nonprofit context, in A Sargeant and W Wymer, (eds) The Routledge Campanion to Nonprofit Marketing, Routledge, Abingdon, Oxford, 11-27.

Philanthropy Australia. 2010. Philanthropy Sector Overview, available at: www.philanthropy.org.au/sector/overview.html (accessed June 2010).

Rodriguez Cano C, Carrillat FA, Jaramillo F. 2004. A meta-analysis of the relationship between market orientation and business performance: evidence from five continents. International Journal of Research in Marketing 21 (2): 179-200.

Sargeant A. 2005. Marketing management for Nonprofit Organizations. 2nd ed. Oxford University Press: Oxford. 
Sargeant A, Foreman S, Liao M. 2002. Operationalizing the marketing concept in the nonprofit sector. Journal of Nonprofit \& Public Sector Marketing 10 (2): 41-65.

Seymour T, Gilbert D, Kolsaker A. 2006. Aspects of market orientation of English and Welsh Charities. Journal of Nonprofit \& Public Sector Marketing 16 (1/2): 151-169.

Sivaramakrishnan S, Zhang D, Delbaere M, Bruning E, 2008 The relationship between organizational commitment and marketing orientation, Journal of Strategic Marketing, 16 (1): $55-73$.

Slater SF, Narver JC. 1994. Does competitive environment moderate the market orientationperformance relationship? Journal of Marketing 58 (January): 46-55.

Smith SC, Santandreu JR. 1997. Marketing in the nonprofit sector - The unique case of art museums. Journal of Nonprofit and Public Sector Marketing 5 (2): 77 - 90.

Sui NYM, Wilson MS 1998 Modelling Market Orientation: An application in the education sector, Journal of Marketing Management, 14, 293-323.

Vazquez R., Alvarez LA. Santos ML. 2002 Market Orientation and social services in private non-profit organisations, European Journal of Marketing, 36, (9/10) 1022-1046.

White DW, Simas CF, 2008 An empirical investigation of the link between marketing orientation and church performance, Int. J. Nonprofit Volunt. Sect. Mark. 13: 153-165.

Wood VR, Bhuian S. 1993. Market orientation and nonprofit organizations: performance associations and research propositions. Journal of Nonprofit and Public Sector Marketing 1 (1): 7-32.

Wrenn B. 1996. What really counts when hospitals adopt a marketing orientation: The contribution of the components of a marketing orientation to hospital performance. Journal of 
Nonprofit \& Public Sector Marketing 4 (1/2): 111-133.

Wrenn B, LaTour S, Calder, J. 1994. Differences in perceptions of hospital marketing orientation between administrators and marketing officers. Hospital and Health Services Administration 39 (3): 341-358.

Zhou Y, Chao P, Huang G. 2009. Modeling market orientation and organizational antecedents in a social marketing context, International Marketing Review, 26 (3): 256-274. 
Table One: Profile of participating organizations by category and size

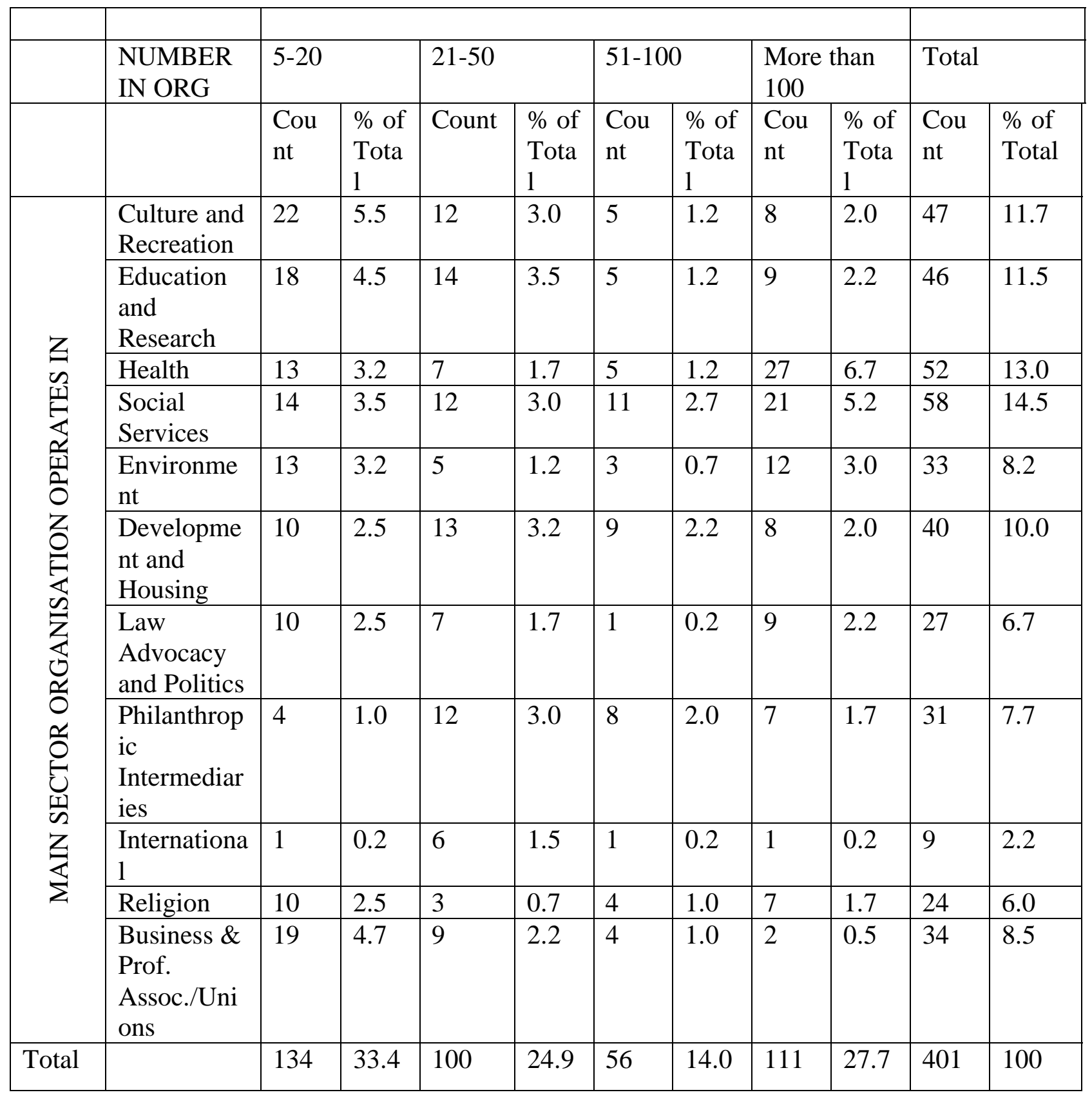


Table Two: Results of survey

\begin{tabular}{|l|l|l|l|}
\hline & Item & Mean & $\begin{array}{c}\text { Std. } \\
\text { Dev }\end{array}$ \\
\hline 1 & Info generated independently by several depts & 3.59 & 0.90 \\
\hline 2 & Survey a sample of donors at least once a year & 3.45 & 1.04 \\
\hline 3 & Regularly compare fund raising performance against others & 3.44 & 1.00 \\
\hline 4 & If others implement new ideas quickly adopt them & 3.34 & 0.97 \\
\hline 5 & Marketing people make strong input into the organization & 3.13 & 1.19 \\
\hline 6 & Top managers within organization regularly discuss others & 3.08 & 1.11 \\
\hline 7 & Donors are liable to switch donations to others & 3.02 & 1.06 \\
\hline 8 & Fund raising performance has been better than others & 2.94 & 0.93 \\
\hline 9 & Regularly check out marketing \& ad activities of others & 2.92 & 1.14 \\
\hline 10 & Have systems to determine value \& frequency of donations & 2.87 & 1.17 \\
\hline 11 & Quickly detect changes in patterns of donations & 2.83 & 1.11 \\
\hline 12 & We set precise targets for our fund raising programs & 2.74 & 1.18 \\
\hline 13 & Marketing people interact frequently with other sections & 2.71 & 1.11 \\
\hline 14 & Often experiment and innovate in use of promotional matter & 2.65 & 1.15 \\
\hline 15 & People and depts get together to plan responses & 2.62 & 1.09 \\
\hline 16 & Fund raising strategies based on understanding motives & 2.57 & 1.09 \\
\hline 17 & Info gathered by marketing people shared with others & 2.55 & 1.06 \\
\hline 18 & Effectiveness of programs frequently evaluated & 2.51 & 1.10 \\
\hline 19 & Have good knowledge of people who donate & 2.39 & 1.11 \\
\hline 20 & Competition for donations is very intense & 2.24 & 1.21 \\
\hline & & 3.14 & 1.36 \\
\hline P & Overall rating of fund raising performance & \\
\hline
\end{tabular}


Table Three: Reliability of scales comparison with Bennett's 1998 study.

\begin{tabular}{|c|c|c|c|c|c|}
\hline $\begin{array}{l}\text { Market } \\
\text { Orientation } \\
\text { Scale }\end{array}$ & $\begin{array}{l}\text { Item } \\
\mathrm{s}\end{array}$ & Items & & $\begin{array}{l}\text { Original } \\
\text { Reliabili } \\
\text { ty }\end{array}$ & $\begin{array}{l}\text { Reliabili } \\
\text { ty This } \\
\text { study }\end{array}$ \\
\hline $\begin{array}{l}\text { Donor } \\
\text { Orientation }\end{array}$ & 6 & $\begin{array}{l}19 \\
2 \\
16 \\
P \\
18 \\
8\end{array}$ & $\begin{array}{l}\text { Have good knowledge of people who donate } \\
\text { Survey a sample of donors at least once a year } \\
\text { Fund raising strategies based on understanding motives } \\
\text { Overall rating of fund raising performance (over past } 5 \mathrm{yrs} \text { ) } \\
\text { Effectiveness of programs frequently evaluated } \\
\text { Fund raising performance has been better than others }\end{array}$ & 0.77 & 0.65 \\
\hline $\begin{array}{l}\text { Competitor } \\
\text { Orientation }\end{array}$ & 5 & $\begin{array}{l}9 \\
4 \\
20 \\
7 \\
6\end{array}$ & $\begin{array}{l}\text { Regularly check out marketing \& ad activities of others } \\
\text { If others implement new ideas quickly adopt them } \\
\text { Competition for donations is very intense } \\
\text { Donors are liable to switch donations to others } \\
\text { Top managers within organization regularly discuss others }\end{array}$ & 0.62 & 0.41 \\
\hline $\begin{array}{l}\text { Influence of } \\
\text { Marketing } \\
\text { Personnel }\end{array}$ & 3 & $\begin{array}{l}13 \\
17 \\
5\end{array}$ & $\begin{array}{l}\text { Marketing people interact frequently with other sections } \\
\text { Info gathered by marketing people shared with others } \\
\text { Marketing people make strong input into the organization }\end{array}$ & 0.72 & 0.60 \\
\hline
\end{tabular}


Table Four: Current model revised factor loadings

\begin{tabular}{|c|c|c|c|c|c|c|}
\hline & & & $\begin{array}{l}\text { DONOR ORIENTATION }(\alpha=0.76), \mathrm{n} \\
6\end{array}$ & & & \\
\hline & New & 11 & $\begin{array}{l}\text { quickly detect changes in patterns of } \\
\text { donations }\end{array}$ & 0.71 & & \\
\hline & New & 10 & $\begin{array}{l}\text { have systems to determine value \& } \\
\text { frequency of donations }\end{array}$ & 0.67 & & \\
\hline Bennett & DO & 18 & $\begin{array}{l}\text { effectiveness of programs frequently } \\
\text { evaluated }\end{array}$ & 0.66 & & \\
\hline Bennett & DO & 19 & $\begin{array}{l}\text { have good knowledge of people who } \\
\text { donate }\end{array}$ & 0.59 & & \\
\hline Bennett & New & 12 & $\begin{array}{l}\text { we set precise targets for our fund } \\
\text { raising programs }\end{array}$ & 0.58 & & \\
\hline \multirow[t]{2}{*}{ Bennett } & DO & 16 & $\begin{array}{l}\text { fund raising strategies based on } \\
\text { understanding motives }\end{array}$ & 0.57 & 0.36 & \\
\hline & & & $\begin{array}{l}\text { MARKETING INTEGRATION }(\alpha= \\
0.67) \text {, n } 5\end{array}$ & & & \\
\hline Bennett & IMP & 17 & $\begin{array}{l}\text { info gathered by marketing people } \\
\text { shared with others }\end{array}$ & & 0.70 & \\
\hline Bennett & IMP & 13 & $\begin{array}{l}\text { marketing people interact frequently } \\
\text { with other sections }\end{array}$ & 0.33 & 0.66 & \\
\hline \multirow[t]{4}{*}{ Bennett } & IMP & 5 & $\begin{array}{l}\text { marketing people make strong input into } \\
\text { the organization }\end{array}$ & & 0.59 & 0.32 \\
\hline & New & 15 & $\begin{array}{l}\text { people and depts get together to plan } \\
\text { responses }\end{array}$ & 0.42 & 0.51 & \\
\hline & New & 14 & $\begin{array}{l}\text { often experiment and innovate in use of } \\
\text { promotional matter }\end{array}$ & & 0.46 & \\
\hline & & & $\begin{array}{l}\text { COMPETITOR ORIENTATION }(\alpha= \\
0.65), 3\end{array}$ & & & \\
\hline Bennett & $\mathrm{CO}$ & 9 & $\begin{array}{l}\text { regularly check out marketing } \& \text { ad } \\
\text { activities of others }\end{array}$ & & & 0.72 \\
\hline \multirow[t]{2}{*}{ Bennett } & $\mathrm{CO}$ & 6 & $\begin{array}{l}\text { top managers within organization } \\
\text { regularly discuss others }\end{array}$ & & 0.40 & 0.68 \\
\hline & New & 3 & $\begin{array}{l}\text { regularly compare fund raising } \\
\text { performance against others }\end{array}$ & & & 0.62 \\
\hline
\end{tabular}


Table Five: Correlation coefficients for fundraising performance and market orientation

\begin{tabular}{|l|l|l|l|}
\hline & Item & Factor & coefficient \\
\hline 8 & $\begin{array}{l}\text { fund raising performance has been better than } \\
\text { others }\end{array}$ & CO & 0.32 \\
\hline 2 & survey a sample of donors at least once a year & BDO & 0.17 \\
\hline 18 & effectiveness of programs frequently evaluated & DO & 0.17 \\
\hline 12 & $\begin{array}{l}\text { we set precise targets for our fund raising } \\
\text { programs }\end{array}$ & DO & 0.16 \\
\hline 10 & $\begin{array}{l}\text { have systems to determine value \& frequency of } \\
\text { donations }\end{array}$ & DO & 0.14 \\
\hline 11 & quickly detect changes in patterns of donations & DO & 0.14 \\
\hline 5 & $\begin{array}{l}\text { marketing people make strong input into the } \\
\text { organization }\end{array}$ & MI & 0.12 \\
\hline 3 & $\begin{array}{l}\text { regularly compare fund raising performance } \\
\text { against others }\end{array}$ & CO & 0.11 \\
\hline 1 & info generated independently by several depts & & 0.11 \\
\hline 13 & $\begin{array}{l}\text { marketing people interact frequently with other } \\
\text { sections }\end{array}$ & MI & 0.09 \\
\hline 19 & have good knowledge of people who donate & BDO & 0.07 \\
\hline 6 & $\begin{array}{l}\text { top managers within organization regularly } \\
\text { discuss others }\end{array}$ & BCO & 0.07 \\
\hline 15 & people and depts get together to plan responses & MI & 0.07 \\
\hline 14 & $\begin{array}{l}\text { often experiment and innovate in use of } \\
\text { promotional matter }\end{array}$ & MI & 0.06 \\
\hline 9 & $\begin{array}{l}\text { regularly check out marketing \& ad activities of } \\
\text { others }\end{array}$ & CO & 0.04 \\
\hline 17 & $\begin{array}{l}\text { info gathered by marketing people shared with } \\
\text { others }\end{array}$ & MI & 0.04 \\
\hline 16 & $\begin{array}{l}\text { fund raising strategies based on understanding } \\
\text { motives }\end{array}$ & DO & 0.03 \\
\hline 4 & $\begin{array}{l}\text { if others implement new ideas quickly adopt } \\
\text { them }\end{array}$ & BCO & -0.07 \\
\hline 7 & donors are liable to switch donations to others & BCO & -0.11 \\
\hline 20 & competition for donations is very intense & BCO & -0.11 \\
\hline P & overall rating of fund raising performance & & 1.00 \\
\hline
\end{tabular}


Table 6 Differences in means by industry

\begin{tabular}{|l|l|l|}
\hline Means by Industry & $\begin{array}{l}\text { Survey a sample of } \\
\text { donors at least once a } \\
\text { year }\end{array}$ & $\begin{array}{l}\text { Info gathered by marketing } \\
\text { people shared with others }\end{array}$ \\
\hline ANOVA (sig) & .024 & .008 \\
\hline $\begin{array}{l}\text { Development \& } \\
\text { Housing }\end{array}$ & 2.70 & 3.23 \\
\hline $\begin{array}{l}\text { Education \& } \\
\text { Research }\end{array}$ & 2.28 & 3.80 \\
\hline $\begin{array}{l}\text { Business \& Prof. } \\
\text { Assoc. / Unions }\end{array}$ & 3.06 & 3.88 \\
\hline Religion & 2.21 & 3.25 \\
\hline $\begin{array}{l}\text { Philanthropic } \\
\text { Intermediaries }\end{array}$ & 2.77 & 3.16 \\
\hline Social Services & 2.57 & 3.17 \\
\hline
\end{tabular}

NB only items with a significant difference have been shown 
Table 7 Differences in means by turnover

\begin{tabular}{|c|c|c|c|c|c|c|}
\hline & & & \multicolumn{4}{|c|}{, $000 \mathrm{~s}$} \\
\hline & Means by Turnover Range & $\begin{array}{l}\text { ANOVA } \\
\text { Sig }\end{array}$ & $<=\$ 100$ & $\begin{array}{l}\$ 100 \\
-\$ 1,000\end{array}$ & $\begin{array}{l}\$ 1,000- \\
\$ 5,000\end{array}$ & $>\$ 5,000+$ \\
\hline 12 & $\begin{array}{l}\text { We set precise targets for our fund } \\
\text { raising programs }\end{array}$ & .016 & 3.01 & 3.087 & 3.35 & 3.59 \\
\hline 3 & $\begin{array}{l}\text { Regularly compare fund raising } \\
\text { performance against others }\end{array}$ & .003 & 2.32 & 2.45 & 2.70 & 2.90 \\
\hline 14 & $\begin{array}{l}\text { Often experiment and innovate in } \\
\text { use of promotional matter }\end{array}$ & .073 & 3.10 & 3.25 & 3.33 & 3.61 \\
\hline 19 & $\begin{array}{l}\text { Have good knowledge of those } \\
\text { who donate }\end{array}$ & .058 & 3.61 & 3.37 & 3.84 & 3.61 \\
\hline 10 & $\begin{array}{l}\text { Have systems to determine value } \\
\& \text { frequency of donations }\end{array}$ & .000 & 2.74 & 2.91 & 3.56 & 3.56 \\
\hline 16 & $\begin{array}{l}\text { Fund raising strategies based on } \\
\text { understanding motives }\end{array}$ & .025 & 3.23 & 3.24 & 3.56 & 3.68 \\
\hline 11 & $\begin{array}{l}\text { Quickly detect changes in patterns } \\
\text { of donations }\end{array}$ & .099 & 3.10 & 2.96 & 3.33 & 3.32 \\
\hline 2 & $\begin{array}{l}\text { Survey a sample of donors at least } \\
\text { once a year \#\# }\end{array}$ & .000 & 2.52 & 2.22 & 2.71 & 2.83 \\
\hline 4 & $\begin{array}{l}\text { If others implement new ideas } \\
\text { quickly adopt them }\end{array}$ & .682 & 2.71 & 2.67 & 2.53 & 2.59 \\
\hline 6 & $\begin{array}{l}\text { Top managers within organizations } \\
\text { regularly discuss others }\end{array}$ & .299 & 2.73 & 2.98 & 3.02 & 2.98 \\
\hline 18 & $\begin{array}{l}\text { Effectiveness of programs } \\
\text { frequently evaluated }\end{array}$ & .283 & 3.37 & 3.39 & 3.59 & 3.67 \\
\hline 15 & $\begin{array}{l}\text { People and departments get } \\
\text { together to plan responses }\end{array}$ & .158 & 3.13 & 3.44 & 3.33 & 3.48 \\
\hline 1 & $\begin{array}{l}\text { Information generated } \\
\text { independently by several } \\
\text { departments } * *\end{array}$ & .046 & 2.30 & 2.26 & 2.60 & 2.24 \\
\hline 9 & $\begin{array}{l}\text { Regularly check out marketing \& } \\
\text { ad activities of others } * *\end{array}$ & .003 & 2.84 & 3.00 & 3.40 & 3.41 \\
\hline \multirow[t]{2}{*}{17} & $\begin{array}{l}\text { Info gathered by marketing people } \\
\text { shared with others }\end{array}$ & .221 & 3.42 & 3.51 & 3.63 & 3.24 \\
\hline & $\begin{array}{l}\text { Marketing people interact } \\
\text { frequently with other sections }\end{array}$ & .084 & 3.05 & 3.24 & 3.48 & 3.43 \\
\hline 13 & $\begin{array}{l}\text { Marketing people make strong } \\
\text { input into the organization }\end{array}$ & .841 & 2.77 & 2.80 & 2.92 & 2.89 \\
\hline 7 & $\begin{array}{l}\text { Donors are liable to switch } \\
\text { donations to others }\end{array}$ & .364 & 2.79 & 2.99 & 2.95 & 3.09 \\
\hline 20 & $\begin{array}{l}\text { Competition for donors is very } \\
\text { intense }\end{array}$ & .000 & 3.44 & 3.63 & 4.16 & 4.20 \\
\hline 8 & $\begin{array}{l}\text { Fund raising performance has been } \\
\text { better than others }\end{array}$ & .016 & 2.85 & 2.98 & 3.15 & 3.31 \\
\hline \multirow[t]{2}{*}{$\mathrm{P}$} & $\begin{array}{l}\text { Overall Rating of Fund Raising } \\
\text { Performance }\end{array}$ & .445 & 3.10 & 3.17 & 3.44 & 3.26 \\
\hline & & & $\mathrm{n}=92$ & $\mathrm{n}=127$ & $n=63$ & $\mathrm{n}=54$ \\
\hline
\end{tabular}

